\title{
Üretim İșletmelerinde Maliyet Analizi: Tuğla Fabrikası Örneği
}

\author{
Ergin TEMEL ${ }^{*}$
}

\begin{abstract}
$\ddot{O} Z$
Üretim maliyetleri, işletmelerin mamul ve hizmet üretebilmek için katlanılan ölçülebilir fedakârlıklar toplamı olarak tanımlanmaktadır. Yoğun rekabetin yaşandı̆̆ı günümüz iş piyasasında üretim maliyetlerinin tespit edilmesi; yönetimin alacă̆ l kararların doğru olması açısından önemlilik arz etmektedir. Üretim maliyetlerinin bulunmasının yananında üretim maliyetlerinin çeşit ve üretim yeri açısından tespit edilerek analiz edilmesi, yöneticilerin maliyet kontrolü ve performans ölçümü için gerekli olmaktadır. Araştırmanın amacı maliyet kontrolü ve performans ölçümü yapmak için tuğla üretiminde ortaya çıkan üretim maliyetlerini, maliyet çeşitleri ve maliyet yerleri açısından tespit ederek elde edilen sonuçları analiz etmektir. Araştırmanın yöntemi gözlem ve görüşmedir. Araştırma için Erbaa bölgesinde tuğla üretimi yapan, günlük üretim kapasitesi 100.000 adet tuğla olan tuğla fabrikasının 2018 ve 2019 yll üretim maliyet verileri kullanılmıştır. Araştırmanın sonucunda 2018 yılı için, üretim maliyetlerinin maliyet etkenleri açısından; \%6'sı direkt ilk madde malzeme maliyetinden, $\% 45$ 'i direkt işçilik maliyetinden, \%49'u genel üretim maliyetinden, maliyet yerleri açısından \%23'ü hammadde hazırlama maliyet yerinde, \%15'i presleme maliyet yerinde, \%19'u kurutma maliyet yerinde, \%43'ü pişirme maliyet yerinde oluştuğu ve birim üretim maliyetinin de 0,114 TL/Kg olduğu tespit edilmiştir. 2019 yll için, üretim maliyetlerinin maliyet etkenleri açısından; $\% 6$ 'sı direkt ilk madde malzeme maliyetinden, \%46'sı direkt işçilik maliyetinden, \%48'i genel üretim maliyetinden, maliyet yerleri açısından \%23'ü hammadde hazırlama maliyet yerinde, \%16's presleme maliyet yerinde, \%18'i kurutma maliyet yerinde, \%43'ü pişirme maliyet yerinde oluştuğu ve birim üretim maliyetinin de 0,135 TL/Kg olduğu tespit edilmiştir. Maliyetleri

Anahtar Kelimeler: Üretim Maliyetleri, Maliyet analizi, Yönetim Muhasebesi, Tuğla
\end{abstract}

JEL Sinıflandırması: M40-M41

\section{Cost Analysis in Production Enterprises: Sample of Brick Factory}

\begin{abstract}
Production costs are defined as the sum of measurable sacrifices that enterprises incur in order to produce goods and services. Determination of production costs in today's labour market where intense competition is experienced; it is important that the decisions taken by the management are correct. Determining and analysing production costs in terms of product and production location is necessary for cost control and performance measurement of managers. The production of bricks is carried out through raw material preparation, pressing, drying and baking stages. Cost types and amounts vary at each stage. The aim of the study is to analyse the results obtained by determining the production costs of brick production in terms of cost elements and cost locations. The method of investigation is observation and interview. The daily production capacity of the Erbaa region for the study was based on the cost of 2018 of the factory with 100,000 bricks. As a result of the research, in terms of cost factors of production costs; direct first material cost-direct labour cost-general production cost-in terms of cost locations-raw material preparation cost location-in press cost
\end{abstract}

*Dr. Öğr. Üyesi. Tokat Gaziosmanpaşa Üniversitesi, Erbaa sağlık bilimler fakültesi, Sağlık Yönetimi Bölümü, Erbaa, Tokat, Türkiye. email:ergin.temel@gop.edu.tr, ORCID Bilgisi: 0000-0003-3572-4722 
location-drying cost are 6\%-45\%-49\%-23\%-15\%-19\% and 43\%, respectively. The unit production cost has been 0,114 TL / Kg too. For 2019, in terms of cost factors of production costs; $6 \%$ is direct raw material cost, $46 \%$ is direct labour cost, $48 \%$ is general production cost. In terms of cost locations; raw material preparation cost $23 \%$, pressing cost $16 \%$, drying $18 \%$ and cooking cost $43 \%$. Additionally, it has been determined that the unit production cost is $0.135 \mathrm{TL} / \mathrm{Kg}$.

Key Words: Production Costs, Cost Analysis, Management Accounting, Brick Costs JEL Classification: M40-M41

\section{GİRIŞ}

Yaşanan yoğun rekabet ortamında işletme yöneticilerinin karar vermelerinde maliyet muhasebesinden elde edilen maliyet verileri doğru kararların alınmasında çok önemlidir. Maliyet verilerinin elde edilmesi kadar bu verilerin zamanlı, ihtiyaca uygun, karşılaştırılabilir, doğru, anlaşılabilir olması da gerekmektedir.

Maliyet analizleri, maliyet muhasebesinden yararlanılarak üretilen maliyet bilgilerinden işletmelerin hem geçmiş dönemlerine ilişkin maliyet verileri ile üretilen mamuller arasındaki ilişkileri yorumlayan hem de işletmelerin geleceğine yönelik kararlar vermede yöneticilere bilgi üreten analizdir.

Faaliyet türü, amacı ve yapısı ne olursa olsun her işletme maliyetlerini ve gelirlerini etkin bir şekilde kontrol altında tutmak zorundadır. Maliyetleri işletme yapısı altında sinıflandırmaya tabi tutarak incelemek ve maliyet unsurlarının içeriğini belirlemek, maliyetlerin denetim altında tutulması ve zamanında müdahaleler için çok önemlidir (Karasioğlu ve Çam, 2008: 17)

Maliyet analizi ile üretim ve hizmet işletmelerinin üretim maliyetleri hem tek yıl verisi kullanılarak ilgili yıl için hem de birden fazla yılın verisi kullanılarak yıllar itibarıyla maliyetlerdeki değişimin analizi yapılabilir.

Maliyet analizleriyle elde edilen veriler kullanılarak işletmelerin üretim maliyetleri, performans değerlemede ve maliyet kontrolünde kullanılabilmektedir.

Sağlık, tarım, enerji gibi değişik sektörlerde maliyet analizi ile ilgili çeşitli araştırmalar yapılmıştır. Bu çalışmada, Türkiye'nin en eski sektörlerinden biri olan tuğla sektöründe üretim maliyetlerinin çeşit ve maliyet yerleri açısından analizinin yapılması amaçlanmıştır. Çalışmada öncelikle maliyet kavramı, maliyet analizi ve tuğla sektörü anlatılmıştır. Uygulama kısmında TR 83 bölgesinde yer alan Erbaa ilçesinde günlük üretim kapasitesi 100.000 adet tuğla olan fabrikanın 2018 ve 2019 yıllarında oluşan üretim maliyetleri analiz edilmiştir.

\section{MALIYET VE MALIYYET ANALIZİ}

Maliyet kavramı hem bilim dünyasında hem iş dünyasında hem de günlük yaşantımızda karşılaşı̆ı̆ımız bir kavramdır. Maliyet kavramı, bir şeyi elde etme, bir şeyi kazanma veya bir şeyi meydana getirme amacıyla katlanılan fedakarlıkların tamamına denir (Abdioğlu, 2013:11).

Üretim maliyetleri maliyet etkenlerine göre, direkt ilk madde ve malzeme maliyeti, direkt işçilik maliyeti ve genel üretim maliyeti (Ertaş, 2016: 19) olmak üzere üç grupta toplanır.

Direkt hammadde ve malzeme maliyeti, işletmelerin üretim faaliyetlerini sürdürebilmesinde kullandığ 1 ve tükettiği her türlü hammadde ve malzemelerin parasal tutarıdır (Ertaş, 1998: 7). Bir malzemenin direkt hammadde ve malzeme 
olarak kabul edilmesinin temel şartı ürünün bünyesi içinde yer almasıdır (Pazarçeviren, 2001: 29). Direkt ilk madde ve malzeme olabilmesi için üretilen mamulün özünü de oluşturması gerekmektedir (Yükcü, 2005: 36).

Direkt işçilik maliyeti, ürünü imal etmek veya hizmeti sağlamak için kullanılan işçiliği içeren (Blocher, Stout and Gary, 2010:66) üretilen mamullere doğrudan doğruya yüklenebilen ve mamullerin temel yapısını oluşturan, hammaddenin biçimini, yapısını ve niteliğini değiştiren işçilikler için oluşan maliyetlerdir (Doğan vd., 2012: 146). Direkt işçilik maliyetleri doğrudan doğruya mamulün üretildiği esas üretim gider merkezlerinde oluşurlar ve hangi mamule ait oldukları kolayca tespit edilebilirler (Şener, 2004: 133).

Genel üretim maliyetleri üretimle ilgili olup, direkt ilk madde ve malzeme ile direkt işçilik maliyetleri dışında kalan tüm endirekt nitelikteki üretim maliyetlerdir (Abdioğlu, 2013: 26). Genel üretim maliyetlerini başta endirekt malzeme ve endirekt işçilik olmak üzere mamulle ilişkisi açısından tüm endirekt maliyetleri oluşturur (Can, 2006: 87).

Maliyet analizi, sistemli olarak bir mamulün veya hizmetin maliyetlerin toplanmasını, sınıflandırılmasını ve incelenmesini sağlayan ekonomik bir değerlendirme yöntemidir (http://onlinefotokopi.com/aof-derskitaplari/aofkaynak.php?dersid=644). Maliyet analizleri, maliyet muhasebe bilgi sisteminden yararlanılarak elde edilen maliyet bilgileriyle hem üretilen mamuller ya da hizmetler arasındaki ilişkilerin yorumlanmasında hem de işletmelerin geleceğine yönelik kararların alınmasında yöneticilere yardımcı olur.

Maliyet analizi için; maliyetlerin sınıflandırılması, tespit edilmesi ve kayıt altına alınması gerekmektedir (Erkol, Ağırbaş, 2011: 88). İşletmelerde ortaya çıkan maliyetlerin bölümlerde izlenmesi hem yönetim muhasebesi hem maliyet muhasebesi hem de finansal muhasebe açısından önemli yararlar sağlar (Kısakürek, 233: 2010). Maliyetlerin bölümlerde izlenmesi, işletmelerin hem üst yönetimine hem de bölüm yönetimine performans ölçümü, maliyetlerin kontrolü ve bütçelerin hazırlanmasinda yardimcı olur.

\section{TUĞLA ÜRETIMI VE ÜRETIM MALIYYTLERI}

Tuğla, killi toprağın üretim aşamalarındaki farklı makinelerde işlenmesi sonucu elde edilir (Temel, 2017: 38). Tuğla fabrikalarındaki üretim akışı Şekil 1'de gösterilmiştir;

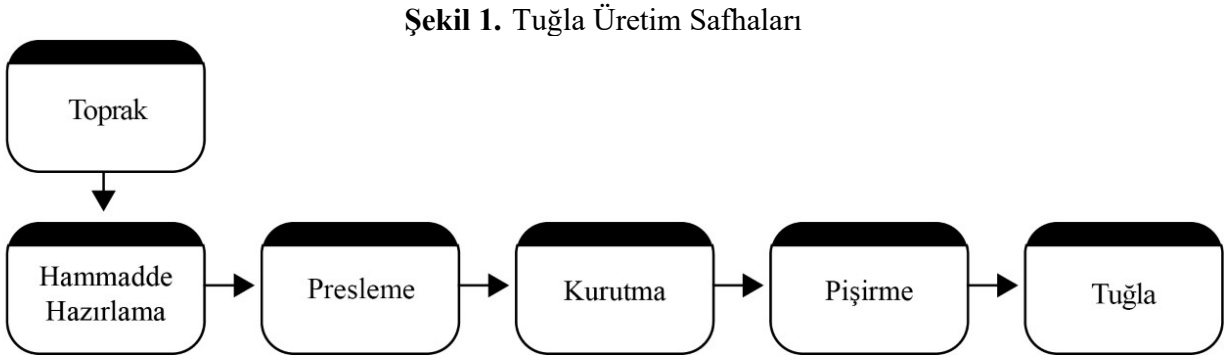

Şekil 1'de görüldüğü üzere tuğla üretimi; stokta bulunan killi toprağın hammadde hazırlama, presleme, kurutma ve pişirme aşamalarından geçerek 
oluşmaktadır. Pişirme aşamasından sonra üretim tamamlanmakta ve mamul haline gelen tuğlalar stok alanlarına taşınmaktadır.

Hammaddenin hazırlanması aşamasında, tuğla üretiminde kullanılan toprağın gerek boyut gerekse bileşim olarak uygun özelliklere sahip olması için bir dizi ön hazırlıklar yapılmaktadır. Bu aşamada, üretimin hammaddesi olan toprağın üretime hazır hale gelebilmesi, homojen bir malzeme olması, plastiklik ve kohezyon özelliklerinin gerçekleşebilmesi için (Şişman ve ark.2006: 33) tezek kırıcı, taş ayırıcı, ezici valsler ve karıştırıcı gibi çeşitli makinelerde işlem görmektedir (Temel, 2017: 40).

Presleme aşamasında, hammadde hazırlama aşaması sonunda şekillendirilmeye uygun hale gelen toprağa, preslerden geçerek tuğla şekli verilmektedir. Presten geçen toprak vakumlanarak içinde havası alınmakta, presin çıkışında bulunan kalıplar sayesinde de değişik boyut ve ölçüde yarı mamul (çiğ) tuğla elde edilmektedir. Pres çıkışında yer alan kesici vasıtasıyla tuğlalar standartlara uygun boyutlarda kesilmektedir (Temel, 2017: 41).

Şekillendirilmiş tuğlaların pişirme öncesi belirli bir mukavemet kazanmaları ve pişirme sırasında şekil değiştirme (rötre) ve çatlamayı engellemek için kurutulması gerekir. Kurutma işlemi normal atmosferik şartlarda doğal olarak yapılabileceği gibi sıcaklığın ve nemin kontrol altında tutulabildiği özel kurutma odalarında da yapılabilir (Öneş, 1988: 67). Kurutma süresi toprağın özelliğine ve mevsime bağlı olarak 24 ile 48 saat arasında değişmektedir (The Brick Industriy, 2006: 3)

Pişirme, tuğla üretimindeki en son aşamadır. Toprak ürünlerinin suyla çözülemez hale gelmesi, sertlik kazanıp fiziksel ve kimyasal dayanıklılığa sahip olması için pişirilmesi gerekmektedir (Bacıoğlu ve Bacıoğlu, 2013: 126). Pişirme için firınlar kullanılmaktadır. Hoffman tipi fırın ve Tünel tipi fırın olmak üzere iki tip firın vardır. Erbaa'da üretim faaliyetinde bulunan fabrikalarda hoffman tipi firın kullanılmaktadır.

Tuğla üretiminin her bir safhasında farklı özelliklerde maliyetler ortaya çıkmaktadır. Tuğla üretimde ortaya çıkan üretim maliyetleri Tablo 1'de gösterilmiştir.

Tablo 1. Tuğla Üretim Maliyetleri

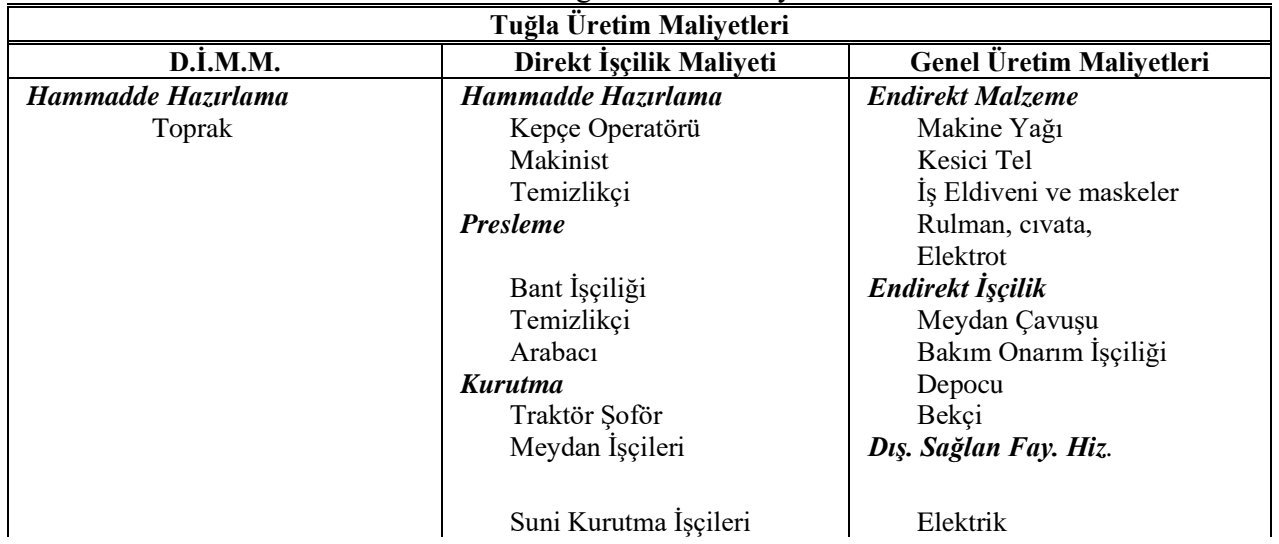




\begin{tabular}{|l|l|l|} 
& Pişirme & Su \\
& Doldurma İşçiliği & Telefon \\
& Boşaltma İşçilik & Nakliye \\
& Kapı Örücü & Yakıt \\
& Kömürcü & Mazot \\
& Ateşçi & Kömür \\
& Külcü & Amortisman \\
& & Vergi Resim Harç \\
& & Sigorta \\
\hline \hline
\end{tabular}

Tablo 1'de tuğla üretiminde ortaya çıkan direkt ilk madde ve malzeme maliyeti, direkt işçilik maliyeti ve genel üretim maliyetleri toplu olarak gösterilmiştir. Tabloda üretim maliyetlerinin çeşitleri ve üretimin hangi aşamasında ortaya çıktığı da ayrıntılı olarak gözükmektedir.

\section{LITERATÜR TARAMASI}

Literatürde değişik sektörlerde yapılan maliyet analiz çalışmalar mevcuttur. Bu araştırmalar ve elde edilen sonuçlar şöyledir;

Kaya çalışmasında Eskişehir bölgesindeki tuğla ve kiremit üretimini ve maliyetlerini incelemiş ve üretim maliyetinin; \%45'ni işçilik, \%12'sini kömür, $\% 12$ 'sini genel giderleri, \%10'nu akaryakıt, \%8'ni elektrik, \%7'sini amortisman ve $\% 6$ 'sını hammadde maliyeti oluşturduğunu tespit etmiştir.

Karasioğlu ve Çam (2008), Karaman Devlet Hastanesi kardiyoloji polikliniği için maliyet analiz yapmış ve araştırma sonucunda kardiyoloji polikliniğinde toplam maliyetin \% 74 'ü direkt işçilik maliyeti, \%3'ü direkt malzeme maliyeti ve \%23'üde genel üretim maliyeti olduğunu bulmuşlardır. Birim muayene maliyetini de 18,87 TL bulmuşlardır.

Soylular ve Ağırbaş (2016), Etimesut Devlet Hastane'sinin 2012 maliyet rakamlarına göre maliyet analizi yapmışlar ve toplam maliyetin \%10,14'ü direkt ilk madde ve malzeme gideri, \%61,29'nu direkt personel gideri, \%28,57'sini genel üretim gideri olarak bulmuşlardır. Toplam üretim maliyetinin \%43,69'u dahili tıp dallarında, \%56,31'i cerrahi tıp bilim dallarında ortaya çıtığını bulmuşlardır. Hastanenin birim maliyet olarak da dahili bilim dallarına ait polikliniklerin birim maliyeti 30,99 TL, cerrahi bilim dallarına ait polikliniklerin birim maliyeti 36,90 TL olduğu bulunmuşlardır.

Esatoğlu vd. (2010), Ankara Üniversitesi İbni Sina Hastanesi'nde maliyet analizi yapmışlar ve toplam giderlerin \%25,51'ini direkt ilk madde ve malzeme gideri, \%54,09'unu direkt işçilik gideri ve \%20,40'ını genel üretim giderleri oluşturduğunu bulmuşlardır.

Kısakürek (2010), Cumhuriyet Üniversitesi Tıp Fakültesi Araştırma Hastanesi'nde maliyet analiz çalışması yapmıştır. Araştırmanın sonucunda, direkt ilk madde ve malzeme giderlerinin $\% 26$, direkt işçilik giderinin $\% 52$ ve genel üretim giderinin $\% 22$ olduğunu bulmuştur.

Büyükmirza (2012), S.B. Türkiye Yüksek İhtisas Eğitim ve Araştırma Hastanesi giderlerini incelemiş ve gider dağılımının \%29,24'ünü direkt ilk madde ve malzeme giderlerinden, \%54,79'unun personel ücret ve giderlerinden ve \%9,89'unun genel üretim giderlerinden oluştuğunu tespit etmiştir. 
Mut ve Ağırbaş (2014), Ankara'da hizmet sunan ikinci basamak bir kamu hastanesinde maliyet araştırması yapmış ve hizmet üretim maliyetinin \%77,76'sını personel gideri, \%18,81'ini genel üretim gideri ve \%3,43'nü direkt ilk madde ve malzeme gideri olarak bulmuşlardır.

Yiğit ve Ağırbaş (2004), Sağlık Bakanlığı Tokat Doğum ve Çocuk Bakımevi Hastanesi'nde maliyet araştırması yapmış ve toplam giderin \%58 personel gideri, \%25,7'si genel üretim gideri ve \%16,3'ü ise direkt ilk madde ve malzeme gideri olduğunu tespit etmişlerdir.

Tuvanç ve Dağdemir (2009), Erzurum İli Pasinler İlçesinde silajlık mısır üretim maliyetinin tespiti üzerine bir araştırma yapmış, toplam giderin $\% 78,58$ 'i değişken gider, \%21,42'si sabit gider olarak tespit etmişlerdir. Değişken giderin $\% 10,36$ 's 1 toprak hazırlama gider, $\% 14,32$ 'si bakım gideri, $\% 25,58$ 'i hasat, nakliye ve slaj yapma masrafi, $\% 23,52$ 'si materyal gideri olarak, sabit giderin $\% 19,06$ 's1 tarla kiras1, \%2,36's1 genel idare gideri olarak bulmuştur. Araştırma sonucunda birim üretim maliyetini $0,066 \mathrm{TL} / \mathrm{Kg}$ olarak bulmuştur.

Demircan vd. (2005) Isparta İlinde elma üretim maliyeti ve gelirinin belirlenmesine yönelik yaptıkları araştırma sonucunda elma üretiminde dekara düşen toplam üretim giderlerinin 776,98 TL olduğunu, üretim giderlerinin \%72,57'sini değişen giderlerden, \%27,43'ünü ise sabit giderlerden oluştuğunu tespit etmişlerdir. Değişken giderin $\% 23,75$, işgücü, $\% 14,27$ 'si makine çekigücü, $\% 25$ materyal, \%9,47 döner sermaye faizi, sabit giderin \%19,69'u arazi faizi, $\% 3,19$ 'u tesis amortisman $1, \% 4,38$ 'i tesis sermaye faizi, $\% 2,18$ 'i genel idare gideri olarak bulunmuş ve üretimden 1,69'da oransal kar tespit etmişledir.

Kadirhanoğulları, Karadaş ve Külekçi (2016), Iğdır İlinde Bal Üretim Maliyetinin Belirlenmesi başlıklı araştırma sonuçlarına göre bal üretim maliyetinde üretim giderlerinin \%63'ünü sabit giderlerden, \%37'sinin değişken giderlerden oluştuğunu, değişken giderlerin \%50'sini şeker, temel petek ve çerçeve masrafları oluştururken sabit giderlerin \% 78 'ini aile işgücü ücret karşllıkları oluşturduğunu ve $1 \mathrm{~kg}$ bal üretim maliyetinin 20,65 TL olduğunu tespit etmişleridir.

\section{TUĞLA FABRIKALARINDA ÜRETIM MALIYETLERININN ANALİí}

A. Amaç

Çalışmanın amacı tuğla fabrikalarında fiili üretim maliyetlerinin maliyet çeşidi ve maliyet yerlerine göre analizini yapmaktır. Çalışma için maliyet verileri TR 83 bölgesinde yer alan Erbaa ilçesindeki tuğla fabrikasından alınmıştır. Fabrikanın 2018 ve 2019 y1lı maliyet verileri kullanılarak üretim maliyetleri analiz edilmiştir. İnceleme yapılan tuğla fabrikasının günlük üretim kapasitesi 100.000 adet tuğla olup, 2018 yılında üç farklı ebatta toplam 21.441.045 adet, 2019 yılında üç farklı ebatta 22.820 .576 adet tuğla üretmiştir.

\section{B. Yöntem}

Araştırmamızın yöntemi gözlem ve görüşmedir. Üretim süreci, üretim yerleri ve maliyetlerin oluşumlarının tespiti için üretim yerlerinde gözlem yapılmıştır. Fabrika yöneticileri ve muhasebe departmanı görevlileri ile görüşülerek maliyet verileri birincil kaynaktan elde edilmiştir. 
Tuğla fabrikasının üretim yerleri fabrika müdür yardımcısıyla birlikte gözlemlenerek maliyet yerleri tespit edilmiştir. 2018 yılı maliyet verilerini elde etmek için müdür yardımcısı ve muhasebe görevlisiyle 9-20 Aralık 2019 tarihleri arasında görüşülmüştür. 2019 yılı maliyet verilerini elde etmek için müdür yardımcısı ve muhasebe görevlisi ile $30 \mathrm{Kasım}-3$ Aralı 2020 tarihleri arasında görüşülmüştür.

\section{Sinırlamalar}

Araştırma Erbaa ilçesindeki tuğla fabrikasında yapılmıştır. Üretim maliyetleri dikkate alınmış, dönem maliyetleri değerleme dışı tutulmuştur. Maliyetler, 2018 ve 2019 yılını kapsamaktadır.

\section{BULGULAR}

Araştırma yaptığımız tuğla fabrikasının 2018 ve 2019 yılında ortaya çıkan üretim maliyetleri Tablo 2'de ve Tablo 3'te gösterilmiştir.

Tablo 2'de görüldüğü üzere tuğla fabrikasının 2018 yılı için direkt ilk madde ve malzeme (toprak) maliyeti $381.251 \mathrm{TL}$, direkt işçilik (makinist, bant işçiliği, traktör şoför işçiliği, firın doldurucu, firın boşaltıcı, ateşçi vb.) maliyeti 2.927.734 TL, genel üretim (makine yağı, tel, maske, eldiven, temizlik işçiliği, elektrik, bakım onarım, mazot, kömür) maliyeti 3.301.537 TL olarak gerçekleşmiştir. Tablo 3'te görüldüğü üzere tuğla fabrikasının 2019 yılı için direkt ilk madde ve malzeme maliyeti $468.938 \mathrm{TL}$, direkt işçilik maliyeti 3.748.415 TL, genel üretim maliyeti 3.966.784TL olarak gerçekleşmiştir.

Tablo 2. 2018 Y1lı Üretim Maliyetleri

\begin{tabular}{|l|r|}
\hline \multicolumn{1}{|c|}{ Maliyet Çeşitleri } & Maliyet Tutarları \\
\hline Direkt İlk Madde ve Malzeme Maliyeti & 381.251 \\
\hline Direkt İşçilik Maliyeti & 2.927 .734 \\
\hline Endirekt Malzeme Maliyeti & 246.000 \\
\hline Endirekt İş̧ilik Maliyeti & 391.680 \\
\hline Elektrik Maliyeti & 644.745 \\
\hline Bakım Onarım Maliyeti & 531.802 \\
\hline Yakıt Maliyeti (Kömür ve mazot) & 1.369 .710 \\
\hline Toplam & $\mathbf{6 . 4 9 2 . 9 2 2}$ \\
\hline
\end{tabular}

Tablo 3. 2019 Üretim Maliyetleri

\begin{tabular}{|l|r|}
\hline \multicolumn{1}{|c|}{ Maliyet Çeşitleri } & \multicolumn{1}{|c|}{ Maliyet Tutarları } \\
\hline Direkt İlk Madde ve Malzeme Maliyeti & 468.938 \\
\hline Direkt İşçilik Maliyeti & 3.748 .415 \\
\hline Endirekt Malzeme Maliyeti & 308.516 \\
\hline Endirekt İş̧ilik Maliyeti & 496.221 \\
\hline Elektrik Maliyeti & 841.891 \\
\hline Bakım Onarım Maliyeti & 665.562 \\
\hline Yakıt Maliyeti (Kömür ve mazot) & 1.654 .594 \\
\hline Toplam & $\mathbf{8 . 1 8 4 . 1 3 8}$ \\
\hline
\end{tabular}

\section{A. Maliyetlerin Dağıtımı}

Araştırma yaptığımız tuğla fabrikasında esas üretim maliyet yeri olarak hammadde hazırlama, presleme, kurutma ve pişirme olarak belirlenmiştir. İşletmede yardımcı hizmet maliyet yerleri olarak üretim yerleri yönetimi maliyet yeri bulunmaktadır. Fabrika bakım ve onarım hizmetini dışarıdan (Erbaa ve Çorum sanayisinden) almaktadır. İşçiler yemek ve kantin hizmetini özel bir işletmeden ücretlerini kendileri ödemek suretiyle almaktadırlar. 
2018 ve 2019 y1l maliyet verilerine göre üretim maliyetlerinin maliyet yerlerine dağıtımında; direkt ilk madde ve malzeme maliyeti ile direkt işçilik maliyeti esas üretim yerlerine direkt olarak dağıtılmıştır. Genel üretim maliyetinden endirekt malzeme maliyeti, bakım onarım maliyeti ile orantılı olarak, endirekt işçilik maliyeti üretim yerlerindeki endirekt işçilerin ücret verilerine göre, elektrik maliyeti, üretim yerlerindeki makinelerin kwh'larına göre dağıtılmıştır. Bakım onarım maliyeti üretim yerlerine göre takibi yapılabildiği için maliyet yerlerine direkt dağıtımı yapılmıştır. Yakıt maliyeti, mazot ve kömür olarak iki çeşidi bulunmaktadır. Kömür firında kullanıldığ 1 için kömür maliyeti direkt pişirme maliyet yerine yüklenmiştir. Mazot maliyeti üretimde kullanılan taşıtların mazot tüketim miktarına göre hesaplanmış ve maliyet yerlerine direkt dağıtılmıştır.

\section{2018 Yılı Maliyetlerinin Dağıtımı}

2018 yılı üretim maliyetlerinin maliyet yerlerine dağıtım (birinci dağıtım) sonucu Tablo 4'te gösterilmiştir.

Tablo 4. 2018 Y1lı Üretim Maliyetlerinin Maliyet Yerlerine Dağıtım Sonucu

\begin{tabular}{|c|c|c|c|c|c|c|}
\hline & & ESAS Ü & RETİM MAI & İYET YERL & ERİ & $\begin{array}{c}\text { Yardımeı } \\
\text { Hizmet } \\
\text { Maliyet Yeri }\end{array}$ \\
\hline & Toplam & $\begin{array}{l}\text { Hammadde } \\
\text { Hazırlama }\end{array}$ & Presleme & Kurutma & Pişirme & $\begin{array}{c}\text { Üretim } \\
\text { Yerleri } \\
\text { Yönetim } \\
\text { Maliyet Yeri }\end{array}$ \\
\hline DİMM & 381.251 & 381.251 & & & & \\
\hline DIM & 2.927 .734 & 170.442 & 652.865 & 509.571 & 1.594 .856 & \\
\hline End. Mlz. & 246.000 & 108.559 & 44.280 & 73.800 & 19.680 & \\
\hline End. İşçilik & 391.680 & 105.783 & 64.670 & 66.365 & 37.262 & 117.600 \\
\hline Elektrik & 644.745 & 284.645 & 128.397 & 186.099 & 45.604 & \\
\hline Bakım Onarım & 531.802 & 234.682 & 95.520 & 159.000 & 42.600 & \\
\hline Yakit & 1.369 .710 & 165.500 & 0 & 187.750 & 1.016 .460 & \\
\hline $\begin{array}{l}\text { 1.Dağıtım } \\
\text { Toplamı }\end{array}$ & 6.492 .922 & 1.450 .862 & 985.732 & 1.182 .585 & 2.756 .462 & 117.600 \\
\hline
\end{tabular}

Tablo 4'te görüldüğü üzere, 6.492.922 TL toplam üretim maliyetine katlanıldığ 1 , bu maliyetin 1.450.862 TL'lik kısmı hammadde hazırlama maliyet yerinde, 985.732 TL'lik kısmı presleme maliyet yerinde, 1.182.585 TL'lik kısm1 kurutma maliyet yerinde, 2.756.462 TL'lik kısmı pişirme maliyet yerinde, 117.600 TL'lik kısmı üretim yerleri yönetim maliyet yerinde gerçekleşmiştir.

İkinci dağım doğrudan dağıtım yöntemi kullanılarak yapılmıştır. İkinci dağıtımda, yardımcı gider yeri olan üretim yerleri yönetimi maliyet yeri maliyeti dağıtılmıştır. Üretim yerleri yönetimi maliyet yeri esas üretim yerlerine eşit hizmet vermektedir. Yardımcı hizmet maliyet yerinin dağıtım (İkinci dağıtım) sonucu oluşan maliyet dağıtım tablosu Tablo 5'te gösterilmiştir. 
Tablo 5. 2018 Yılı Yardımcı Hizmet Maliyet Yerinin Dağıtım Sonucu

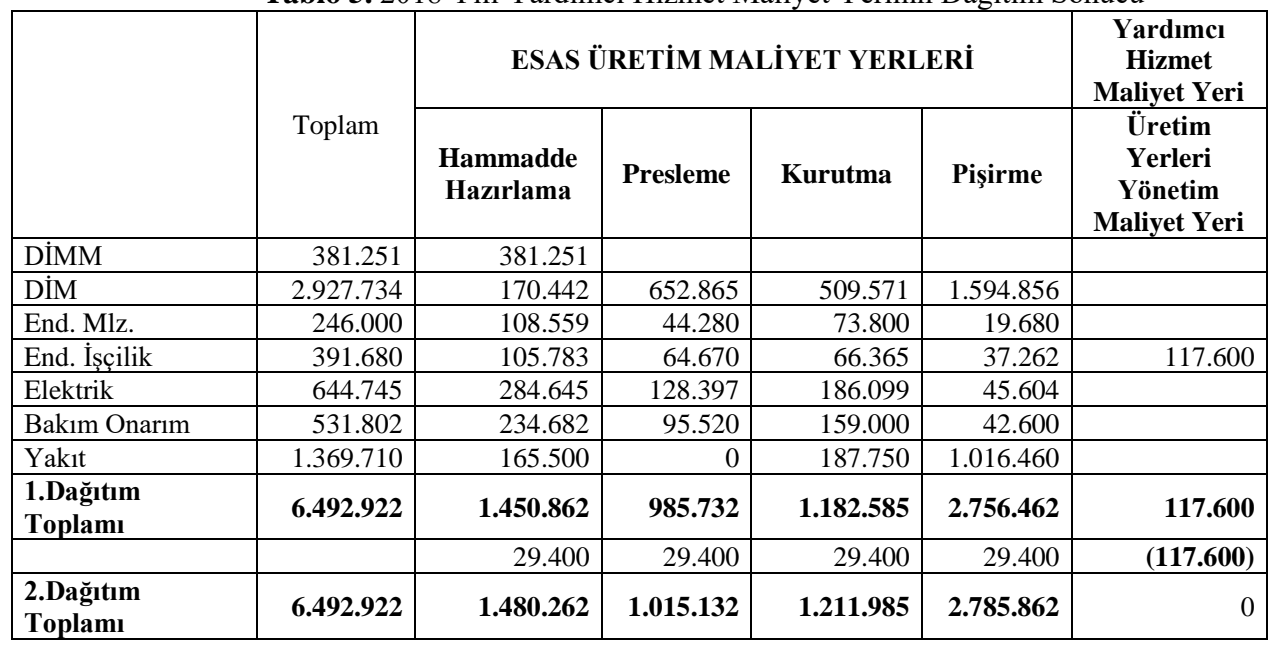

Tablo 5'te görüleceği üzere ikinci dağıtım sonucu üretim yerleri yönetimi maliyet yerinde oluşan 117.600 TL esas üretim yerleri dağıtılmıştır. Dağıtım sonucunda hammadde hazırlama maliyeti yerinde 1.480.262 TL, presleme maliyet yerinde 1.015.132 TL, kurutma maliyet yerinde 1.211.985 TL, pişirme maliyet yerinde 2.785.862 TL maliyet oluşmuştur.

\section{2019 Yılı Maliyetlerinin Dağıtımı}

2019 y1lı üretim maliyetlerinin maliyet yerlerine dağıtım (birinci dağıtım) sonucu Tablo 6'da gösterilmiştir.

Tablo 6. 2019 Yılı Üretim Maliyetlerinin Maliyet Yerlerine Dağıtım Sonucu

\begin{tabular}{|c|c|c|c|c|c|c|}
\hline & \multirow{2}{*}{ Toplam } & \multicolumn{4}{|c|}{ ESAS ÜRETIMM MALİYET YERLERİ } & \multirow{2}{*}{$\begin{array}{c}\begin{array}{c}\text { Yardımc } \\
\text { Hizmet } \\
\text { Maliyet Yeri }\end{array} \\
\text { Üretim } \\
\text { Yerleri } \\
\text { Yönetim } \\
\text { Maliyet Yeri } \\
\end{array}$} \\
\hline & & $\begin{array}{c}\text { Hammadde } \\
\text { Hazirlama }\end{array}$ & Presleme & Kurutma & Pişirme & \\
\hline DİMM & 468.938 & 468.938 & & & & \\
\hline DİM & 3.748 .415 & 214.757 & 829.139 & 647.155 & 2.057 .365 & \\
\hline End. Mlz. & 308.516 & 141.127 & 58.765 & 84.583 & 24.042 & \\
\hline End. İşçilik & 496.221 & 135.403 & 80.896 & 83.032 & 46.362 & 150.528 \\
\hline Elektrik & 841.891 & 370.039 & 166.916 & 245.651 & 59.285 & \\
\hline Bakım Onarım & 665.562 & 293.352 & 109.848 & 214.650 & 47.712 & \\
\hline Yakıt & 1.654 .594 & 198.600 & & 215.913 & 1.240 .081 & \\
\hline $\begin{array}{l}\text { 1.Dağıtım } \\
\text { Toplamı }\end{array}$ & 8.184.138 & 1.822.216 & 1.245 .564 & 1.490 .983 & 3.474.847 & 150.528 \\
\hline
\end{tabular}

Tablo 6'da görüldüğü üzere, 8.184.138 TL toplam üretim maliyetine katlanıldı̆̆ 1 , bu maliyetin 1.822.216 TL'lik kısmı hammadde hazırlama maliyet yerinde, 1.245.564 TL'lik kısmı presleme maliyet yerinde, 1.490.983TL'lik kısm1 kurutma maliyet yerinde, 3.474.847 TL'lik kısmı pişirme maliyet yerinde, 150.528 TL'lik kısmı üretim yerleri yönetim maliyet yerinde gerçekleşmiştir.

Yardımcı hizmet maliyet yerinin dağıtım (ikinci dağıtım) sonucu oluşan maliyet dağıtım tablosu Tablo 7'de gösterilmiştir. 
Tablo 7. 2019 Yılı Yardımcı Hizmet Maliyet Yerinin Dağıtım Sonucu

\begin{tabular}{|c|c|c|c|c|c|c|}
\hline & \multirow[b]{2}{*}{ Toplam } & \multicolumn{4}{|c|}{ ESAS ÜRETIMM MALIYET YERLERİ } & \multirow{2}{*}{$\begin{array}{c}\begin{array}{c}\text { Yardımcı } \\
\text { Hizmet } \\
\text { Maliyet Yeri }\end{array} \\
\text { Üretim } \\
\text { Yerleri } \\
\text { Yönetim } \\
\text { Maliyet Yeri }\end{array}$} \\
\hline & & $\begin{array}{c}\text { Hammadde } \\
\text { Hazırlama }\end{array}$ & Presleme & Kurutma & Pişirme & \\
\hline DİMM & 468.938 & 468.938 & & & & \\
\hline DİM & 3.748 .415 & 214.757 & 829.139 & 647.155 & 2.057 .365 & \\
\hline End. Mlz. & 308.516 & 141.127 & 58.765 & 84.583 & 24.042 & \\
\hline End. İşçilik & 496.221 & 135.403 & 80.896 & 83.032 & 46.362 & 150.528 \\
\hline Elektrik & 841.891 & 370.039 & 166.916 & 245.651 & 59.285 & \\
\hline Bakım Onarım & 665.562 & 293.352 & 109.848 & 214.650 & 47.712 & \\
\hline Yakit & 1.654 .594 & 198.600 & & 215.913 & 1.240 .081 & \\
\hline \multirow[t]{2}{*}{$\begin{array}{l}\text { 1.Dağıtım } \\
\text { Toplamı }\end{array}$} & 8.184.138 & 1.822.216 & 1.245 .564 & 1.490 .983 & 3.474.847 & 150.528 \\
\hline & & 37.632 & 37.632 & 37.632 & 37.632 & $(150.528)$ \\
\hline $\begin{array}{l}\text { 2.Dağıtım } \\
\text { Toplamı }\end{array}$ & 8.184.138 & 1.859 .848 & 1.283 .196 & 1.528.615 & 3.512.479 & 0 \\
\hline
\end{tabular}

Tablo 7'de görüleceği üzere 2. dağıtım sonucu üretim yerleri yönetimi maliyet yerinde oluşan 150.528 TL esas üretim yerleri dağıtılmıştır. Dağıtım sonucunda hammadde hazırlama maliyeti yerinde 1.859.848 TL, presleme maliyet yerinde 1.283.196 TL, kurutma maliyet yerinde 1.528.615 TL, pişirme maliyet yerinde 3.512.479 TL maliyet oluşmuştur.

\section{B. Maliyetlerin Analizi}

Elde ettiğimiz maliyet verilerini analize uygun hale getirmek için maliyet türlerine ve maliyet yerlerine göre ayrı ayrı tablolar oluşturulmuştur.

\section{2018 Yılı Maliyetlerinin Analizi}

2018 y1lı üretim maliyet verilerini maliyet türlerine göre analiz etmek için Tablo 8 oluşturulmuştur.

Tablo 8. Maliyet Türlerine Göre 2018 Maliyetleri

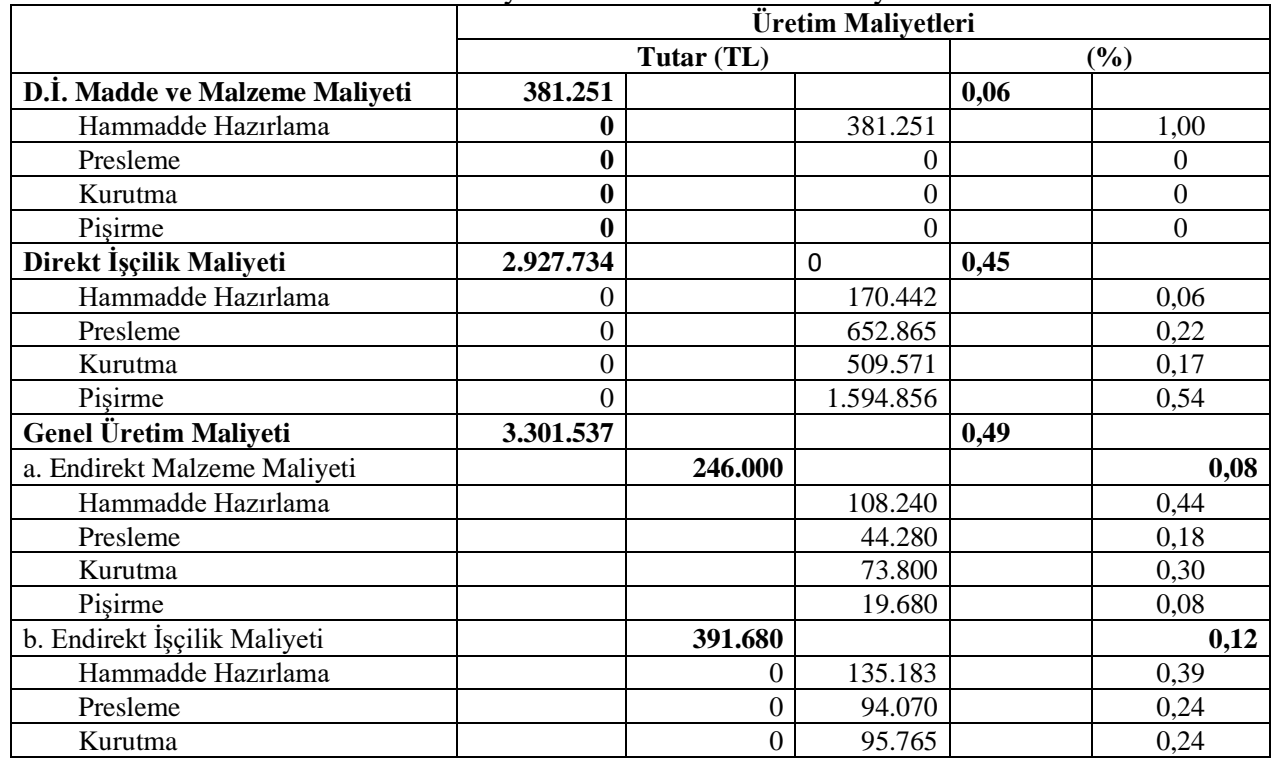




\begin{tabular}{|c|r|r|r|r|c|}
\hline Pişirme & & 0 & 66.662 & & 0,14 \\
\hline c. Elektrik Maliyeti & & $\mathbf{6 4 4 . 7 4 5}$ & & & $\mathbf{0 , 2 0}$ \\
\hline Hammadde Hazırlama & & & 284.645 & & 0,44 \\
\hline Presleme & & & 128.397 & & 0,20 \\
\hline Kurutma & & & 186.099 & & 0,29 \\
\hline Pişirme & & & 45.604 & & 0,07 \\
\hline d. Bakım Onarım Maliyeti & & $\mathbf{5 3 1 . 8 0 2}$ & & & $\mathbf{0 , 1 7}$ \\
\hline Hammadde Hazırlama & & & 234.682 & & 0,44 \\
\hline Presleme & & & 95.520 & & 0,18 \\
\hline Kurutma & & & 159.000 & & 0,30 \\
\hline Pişirme & & & 42.600 & & 0,08 \\
\hline e. Yakıt Maliyeti & & $\mathbf{1 . 3 6 9 . 7 1 0}$ & & & $\mathbf{0 , 4 3}$ \\
\hline Hammadde Hazırlama & & & 165.500 & & 0,12 \\
\hline Presleme & & & & 0 & \\
\hline Kurutma & & & 187.750 & & 0,00 \\
\hline Pişirme & & & 1.016 .460 & & 0,74 \\
\hline Üretim Maliyeti & $\mathbf{6 . 4 9 2 . 9 2 2}$ & & & & \\
\hline
\end{tabular}

Tablo 8'de görüldüğü üzere üretim maliyetleri hem tutar hem de yüzde olarak değerlendirilmiştir. 2018 y1lı toplam üretim maliyetinin 6.492 .922 TL olduğu tespit edilmiştir. Toplam üretim maliyetinin 381.251 TL'lik kısmı (\%6's1) direkt ilk madde ve malzeme maliyeti, 2.927.734 TL'lik kısmı (\%45'i) direkt işçilik maliyeti ve 3.301.537 TL'lik kısmı (\%49'u) genel üretim maliyeti olarak gerçekleşmiştir.

Direkt ilk madde ve malzeme maliyeti açısından değerlendirdiğimizde tuğlanın hammaddesi olan killi toprağın üretimin ilk aşaması olan hammadde hazırlama aşamasında üretime alındığ 1 için sadece bu aşamada direkt ilk madde ve malzeme maliyeti oluşmuştur.

Üretim maliyetleri içerisinde $\% 45$ paya sahip olan direkt işçilik maliyetinin maliyet yerleri açısından değerlendirildiğinde; \%6'sı hammadde hazırlama maliyet yerinde, $\% 22$ 'si presleme maliyet yerinde, $\% 17$ 'si kurutma maliyet yerinde, $\% 54$ 'ü pişirme maliyet yerinde oluştuğu tespit edilmiştir. Direkt işçilik maliyetinin maliyet yerleri açısından \%50'den fazlası pişirme aşamasındaki maliyet yerinde ortaya çıkması bu maliyet yerinin direkt işçilik maliyeti açısından ne kadar önemli olduğunu göstermektedir.

Üretim maliyetinin \%49'luk kısmını oluşturan genel üretim maliyetinin \%8'i endirekt malzeme maliyeti için, \%12'si endirekt işçilik maliyeti için, \%20'si enerji (elektrik) maliyeti için, \%17'si bakım onarım maliyeti için ve \%43'ü yakıt (mazot ve kömür) maliyeti için ortaya çıktığı tespit edilmiştir. Endirekt malzeme maliyeti \%44'lük payla en fazla hammadde hazırlama maliyet yerinde oluşmuştur. Endirekt işçilik maliyeti de \%39'luk payla en fazla yine hammadde hazırlama maliyet yerinde oluşmuştur. Elektrik maliyeti de \%44'lük payla en fazla yine hammadde hazırlama maliyet yerinde ortaya çıkmıştır. Yakıt maliyeti haricindeki genel üretim maliyetlerinin çoğunluğu hammadde hazırlama maliyet yerinde ortaya çıkmıştır. Genel üretim maliyetinin en önemli kısmını (\%43'lük payla) yakıt maliyeti oluşturmaktadır. Yakıt maliyetinin maliyet yeri bakımından \% 74'lik payla en fazla pişirme maliyet yerinde ortaya çıktığ 1 tespit edilmiştir.

Maliyet yerlerine göre 2018 maliyetlerini analiz etmek için Tablo 9 oluşturulmuştur. 
Tablo 9. Üretim Yerlerine Göre 2018 Maliyetleri

\begin{tabular}{|c|c|c|c|c|}
\hline \multicolumn{3}{|c|}{ HAMMADDE HAZIRLAMA MALIYYET YERİ } & \multirow{2}{*}{$\begin{array}{c}\text { Maliyet Yeri } \\
0.26\end{array}$} & \multirow[t]{2}{*}{ Genel } \\
\hline Direkt İlk Madde ve Malzeme Maliyeti & & 381.251 & & \\
\hline Direkt İşçilik Maliyeti & & 170.442 & 0,12 & \\
\hline Genel Üretim Maliyeti & & 928.570 & 0,62 & \\
\hline a. Endirekt Malzeme & 108.559 & & 0,12 & \\
\hline b. Endirekt İșçilik & 135.183 & & 0,15 & \\
\hline c. Enerji (Elektrik) & 284.645 & & 0,30 & \\
\hline d. Bakım Onarım & 234.682 & & 0,25 & \\
\hline e. Yakıt (Mazot) & 165.500 & & 0,18 & \\
\hline H. Hazrrlama Maliyet Yeri Üretim Maliyeti & & 1.480 .262 & & $\mathbf{0 , 2 3}$ \\
\hline \multicolumn{5}{|l|}{ PRESLEME MALIYYET YERİ } \\
\hline Direkt İlk Madde ve Malzeme Maliyeti & & - & & \\
\hline Direkt İşçilik Maliyeti & & 652.865 & 0,64 & \\
\hline Genel Üretim Maliyeti & & 362.171 & 0,36 & \\
\hline a. Endirekt Malzeme & 44.184 & & 0,12 & \\
\hline b. Endirekt İşçilik & 94.070 & & 0,26 & \\
\hline c. Enerji (Elektrik) & 128.397 & & 0,35 & \\
\hline d. Bakım Onarım & 95.520 & & 0,26 & \\
\hline Presleme Maliyet Yeri Üretim Maliyeti & & 1.015 .037 & & $\mathbf{0 , 1 5}$ \\
\hline \multicolumn{5}{|l|}{ KURUTMA MALIYYET YERİ } \\
\hline Direkt İlk Madde ve Malzeme Maliyeti & & - & & \\
\hline Direkt İşçilik Maliyeti & & 509.571 & 0,42 & \\
\hline Genel Üretim Maliyeti & & 702.164 & 0,58 & \\
\hline a. Endirekt Malzeme & 73.550 & & 0,10 & \\
\hline b. Endirekt İşçilik & 95.765 & & 0,14 & \\
\hline c. Enerji (Elektrik) & 186.099 & & 0,27 & \\
\hline d. Bakım Onarım & 159.000 & & 0,23 & \\
\hline e. Yakıt (Mazot) & 187.750 & & 0,27 & \\
\hline Kurutma Maliyet Yeri Üretim Maliyeti & & 1.211 .735 & & $\mathbf{0 , 1 9}$ \\
\hline \multicolumn{5}{|l|}{ PISSSiRME MALIYYT YERİ } \\
\hline Direkt İlk Madde ve Malzeme Maliyeti & & - & & \\
\hline Direkt İşçilik Maliyeti & & 1.594 .856 & 0,57 & \\
\hline Genel Üretim Maliyeti & & 1.191 .033 & 0,43 & \\
\hline a. Endirekt Malzeme & 19.706 & & 0,02 & \\
\hline b. Endirekt İşçilik & 66.662 & & 0,05 & \\
\hline c. Enerji (Elektrik) & 45.604 & & 0,04 & \\
\hline d. Bakım Onarım & 42.600 & & 0,04 & \\
\hline e. Yakit (Mazot) & 34.800 & & 0,03 & \\
\hline f. Kömür & 981.660 & & 0,82 & \\
\hline Pişirme Maliyet Yeri Üretim Maliyeti & & 2.785 .889 & & $\mathbf{0 , 4 3}$ \\
\hline TOPLAM ÜRETIM MALIYETİ & & 6.492 .922 & & \\
\hline
\end{tabular}

Tablo 9'da görüldüğü üzere toplam 6.492.922 TL'lik üretim maliyetinin; 1.480.262 TL'lik kısmı (\%23'ü) hammadde hazırlama maliyet yerinde, 1.015.037 TL'lik k1smı (\%15'i) presleme maliyet yerinde, 1.211.735 TL'lik k1smı (\%19'u) kurutma maliyet yerinde ve 2.785.889 TL'lik kısmı (\%43'ü) pişirme maliyet yerinde oluşmuştur.

Hammadde hazırlama maliyet yerinde ortaya çıkan 1.480.262 TL'lik üretim maliyetinin 381.251 TL'lik k1smı (\%26's1) direkt ilk madde ve malzeme maliyeti, 170.442 TL'lik kısmı (\%12'si) direkt işçilik maliyeti, 928.570 TL'lik kısmı (\%62'si) genel üretim maliyetinden oluşmuştur. Genel üretim maliyetinde de bakım onarım ve enerji (elektrik) maliyeti önemli paya sahiptir.

Presleme maliyet yerinde ortaya çıkan 1.015.037 TL'lik üretim maliyetinin 652.865 TL'lik kısmı (\%66'sı) direkt işçilik maliyeti, 362.171 TL'lik kısmı (\%34'ü) genel üretim maliyetinden oluşmaktadır. Genel üretim maliyetinin \%35'i 
enerji (elektrik), \%26's1 endirekt işçilik ve \%26'sı bakım onarım maliyetinden kaynaklanmaktadır.

Kurutma maliyet yerinde ortaya çıkan 1.211.735 TL'lik üretim maliyetinin 509.571 TL'lik kısmı (\%42'si) direkt işçilik maliyeti, 702.164TL'lik kısmı (\%58'si) genel üretim maliyetinden oluşmaktadır. Genel üretim maliyetlerinde de enerji, bakım onarım ve yakıt maliyetinin önemli paya sahip olduğu gözükmektedir.

Üretim maliyetinin en fazla ortaya çıkan maliyet yeri pişirme maliyet yeridir. Pişirme maliyet yerinde ortaya çıkan 2.785.889 TL'lik üretim maliyetinin 1.594.856 TL'lik kısmı (\%58'i) direkt işçilik maliyeti, 1.191.033 TL'lik kısmı (\%42'si) genel üretim maliyetinden oluşmaktadır. Genel üretim maliyetinde de kömür maliyetinin toplam maliyetinin \%82'sine sahip olduğu tespit edilmiştir.

\section{2019 Yılı Maliyetlerinin Analizi}

2019 y1lı üretim maliyet verilerini maliyet türlerine göre analiz etmek için Tablo 10 oluşturulmuştur.

Tablo 10. Maliyet Türlerine Göre 2019 Maliyetleri

\begin{tabular}{|c|c|c|c|c|c|}
\hline \multirow[b]{3}{*}{ D.İ.Madde ve Malzeme Maliyeti } & \multicolumn{5}{|c|}{ Üretim Maliyetleri } \\
\hline & \multicolumn{3}{|c|}{ Tutar (TL) } & \multicolumn{2}{|c|}{$(\%)$} \\
\hline & 468.938 & & & 0,06 & \\
\hline Hammadde Hazırlama & & & 468.938 & & 1,00 \\
\hline \multicolumn{6}{|l|}{ Presleme } \\
\hline \multicolumn{6}{|l|}{ Kurutma } \\
\hline \multicolumn{6}{|l|}{ Pișirme } \\
\hline Direkt İşçilik Maliyeti & 3.748 .415 & & & 0,46 & \\
\hline Hammadde Hazırlama & & & 214.757 & & 0,06 \\
\hline Presleme & & & 829.139 & & 0,22 \\
\hline Kurutma & & & 647.155 & & 0,17 \\
\hline Pișirme & & & 2.057 .365 & & 0,55 \\
\hline Genel Üretim Maliyeti & 3.966 .784 & & & 0,48 & \\
\hline a. Endirekt Malzeme Maliyeti & & 308.516 & & & $\mathbf{0 , 0 8}$ \\
\hline Hammadde Hazırlama & & & 141.127 & & 0,46 \\
\hline Presleme & & & 58.765 & & 0,19 \\
\hline Kurutma & & & 84.583 & & 0,27 \\
\hline Pișirme & & & 24.042 & & 0,08 \\
\hline b. Endirekt İşçilik Maliyeti & & 496.221 & & & 0,13 \\
\hline Hammadde Hazırlama & & & 173.035 & & 0,35 \\
\hline Presleme & & & 118.528 & & 0,24 \\
\hline Kurutma & & & 120.664 & & 0,24 \\
\hline Pişirme & & & 83.994 & & 0,17 \\
\hline c. Elektrik Maliyeti & & 841.891 & & & 0,21 \\
\hline Hammadde Hazırlama & & & 370.039 & & 0,44 \\
\hline Presleme & & & 166.916 & & 0,20 \\
\hline Kurutma & & & 245.651 & & 0,29 \\
\hline Pișirme & & & 59.285 & & 0,07 \\
\hline d. Bakım Onarım Maliyeti & & 665.562 & & & 0,17 \\
\hline Hammadde Hazırlama & & & 293.352 & & 0,44 \\
\hline Presleme & & & 109.848 & & 0,17 \\
\hline Kurutma & & & 214.650 & & 0,32 \\
\hline Pișirme & & & 47.712 & & 0,07 \\
\hline e. Yakıt Maliyeti & & 1.654 .594 & & & 0,42 \\
\hline Hammadde Hazırlama & & & 198.600 & & 0,12 \\
\hline \multicolumn{6}{|l|}{ Presleme } \\
\hline Kurutma & & & 215.913 & & 0,13 \\
\hline Pișirme & & & 1.240 .081 & & 0,75 \\
\hline Üretim Maliyeti & 8.184 .138 & & & & \\
\hline
\end{tabular}

Tablo 10'da görüldügüü üzere 2019 yılı toplam üretim maliyeti 8.184.138 TL olarak gerçekleşmiştir. Toplam üretim maliyetinin 468.938 TL'lik kısm1 
(\%6's1) direkt ilk madde ve malzeme maliyeti, 3.748.415 TL'lik kısmı (\%46's1) direkt işçilik maliyeti ve 3.966.784 TL'lik kısmı (\%48'i) genel üretim maliyeti olarak gerçekleşmiştir.

Üretim maliyetleri içerisinde \%46'lık paya sahip olan direkt işçilik maliyetinin $\% 6$ 's hammadde hazırlama maliyet yerinde, $\% 22$ 'si presleme maliyet yerinde, \%17'si kurutma maliyet yerinde ve \%55'i pişirme maliyet yerinde oluştuğu tespit edilmiştir.

Üretim maliyetinin \%48'lik kısmını oluşturan genel üretim maliyetinin \%8'i endirekt malzeme maliyeti için, \%13'ü endirekt işçilik maliyeti için, \%21'i enerji (elektrik) maliyeti için, \%17'si bakım onarım maliyeti için ve \%42'si yakıt (mazot ve kömür) maliyeti için ortaya çıktığı tespit edilmiştir. Endirekt malzeme maliyeti \%46'lık payla, endirekt işçilik maliyeti \%35'lik payla, elektrik maliyeti de \%44'lük payla en fazla yine hammadde hazırlama maliyet yerinde ortaya çıkmıştır. Genel üretim maliyetinin en önemli kısmını \%42'lik payla yakıt maliyeti oluşturmaktadır. Yakıt maliyetinin maliyet yeri bakımından \% 75'lik payla en fazla pişirme maliyet yerinde ortaya çıktığı tespit edilmiştir. 2019 maliyet verilerine göre de yakıt maliyeti hariç genel üretim maliyetleri en fazla hammadde hazırlama maliyet yerinde ortaya çıkmışır.

Maliyet yerlerine göre 2019 maliyetlerini analiz etmek için Tablo 11 oluşturulmuştur.

Tablo 11. Üretim Yerlerine Göre 2019 Maliyetleri

\begin{tabular}{|c|c|c|c|c|}
\hline \multicolumn{3}{|c|}{ HAMMADDE HAZIRLAMA MALIYET YERİ } & \multirow{2}{*}{$\begin{array}{r}\text { Maliyet Yeri } \\
0,25\end{array}$} & \multirow[t]{2}{*}{ Genel } \\
\hline Direkt İlk Madde ve Malzeme Maliyeti & & 468.938 & & \\
\hline Direkt İşçilik Maliyeti & & 214.757 & 0,12 & \\
\hline Genel Üretim Maliyeti & & 1.176 .153 & 0,63 & \\
\hline a. Endirekt Malzeme & 141.127 & & 0,12 & \\
\hline b. Endirekt İşçilik & 173.035 & & 0,15 & \\
\hline c. Enerji (Elektrik) & 370.039 & & 0,31 & \\
\hline d. Bakım Onarım & 293.352 & & 0,25 & \\
\hline e. Yakıt (Mazot) & 198.600 & & 0,17 & \\
\hline H. Hazırlama Maliyet Yeri Üretim Maliyeti & & $\mathbf{1 . 8 5 9 . 8 4 8}$ & & $\mathbf{0 , 2 3}$ \\
\hline \multicolumn{5}{|l|}{ PRESLEME MALIYET YERI } \\
\hline \multicolumn{5}{|l|}{ Direkt İlk Madde ve Malzeme Maliyeti } \\
\hline Direkt İşçilik Maliyeti & & 829.139 & 0,65 & \\
\hline Genel Üretim Maliyeti & & 454.057 & 0,35 & \\
\hline a. Endirekt Malzeme & 58.765 & & 0,13 & \\
\hline b. Endirekt İşçilik & 118.528 & & 0,26 & \\
\hline c. Enerji (Elektrik) & 166.916 & & 0,37 & \\
\hline d. Bakım Onarım & 109.848 & & 0,24 & \\
\hline Presleme Maliyet Yeri Üretim Maliyeti & & 1.283 .196 & & 0,16 \\
\hline \multicolumn{5}{|l|}{ KURUTMA MALIYET YERI } \\
\hline Direkt İlk Madde ve Malzeme Maliyeti & & & & \\
\hline Direkt İşçilik Maliyeti & & 647.155 & 0,42 & \\
\hline Genel Üretim Maliyeti & & 881.460 & 0,58 & \\
\hline a. Endirekt Malzeme & 84.583 & & 0,10 & \\
\hline b. Endirekt İş̧̧ilik & 120.664 & & 0,14 & \\
\hline c. Enerji (Elektrik) & 245.651 & & 0,28 & \\
\hline d. Bakım Onarım & 214.650 & & 0,24 & \\
\hline e. Yakıt (Mazot) & 215.913 & & 0,24 & \\
\hline
\end{tabular}




\begin{tabular}{|l|r|r|r|r|}
\hline Kurutma Maliyet Yeri Üretim Maliyeti & & $\mathbf{1 . 5 2 8 . 6 1 5}$ & & $\mathbf{0 , 1 8}$ \\
\hline \multicolumn{1}{|c|}{ PİşíRME MALiYET YERI } & & & & \\
\hline Direkt İlk Madde ve Malzeme Maliyeti & & & & \\
\hline Direkt İş̧ilik Maliyeti & & 2.057 .365 & 0,59 & \\
\hline Genel Üretim Maliyeti & & 1.455 .114 & 0,41 & \\
\hline a. Endirekt Malzeme & 24.042 & & 0,02 & \\
\hline b. Endirekt İşçilik & 83.994 & & 0,06 & \\
\hline c. Enerji (Elektrik) & 59.285 & & 0,04 & \\
\hline d. Bakım Onarım & 47.712 & & 0,03 & \\
\hline e. Yakıt (Mazot) & 40.368 & & 0,03 & \\
\hline f. Kömür & 1.199 .713 & & 0,82 & \\
\hline Pişirme Maliyet Yeri Üretim Maliyeti & & $\mathbf{3 . 5 1 2 . 4 7 9}$ & & $\mathbf{0 , 4 3}$ \\
\hline TOPLAM ÜRETiM MAL̇IYETİ & & $\mathbf{8 . 1 8 4 . 1 3 8}$ & & \\
\hline
\end{tabular}

Tablo 11'de görüldügüü üzere toplam 8.184.138 TL'lik üretim maliyetinin; 1.859.848 TL'lik kısmı (\%23'ü) hammadde hazırlama maliyet yerinde, 1.283.196 TL'lik k1smı (\%16's1) presleme maliyet yerinde, 1.528.615 TL'lik kısmı (\%18'i) kurutma maliyet yerinde ve 3.512.479 TL'lik kısmı (\%43'ü) pişirme maliyet yerinde oluşmuştur.

Hammadde hazırlama maliyet yerinde ortaya çıkan 1.859.848 TL'lik üretim maliyetinin 468.938 TL'lik kısmı (\%25'i) direkt ilk madde ve malzeme maliyetinden, 214.757 TL'lik kısmı (\%12'si) direkt işçilik maliyetinden, 1.176.153 TL’lik kısmı (\%63’ü) genel üretim maliyetinden oluşmuştur.

Presleme maliyet yerinde ortaya çıkan 1.283.196 TL'lik üretim maliyetinin 829.139 TL'lik kısmı (\%65'i) direkt işçilik maliyetinden, 454.057 TL'lik kısmı (\%35'i) genel üretim maliyetinden oluşmaktadır.

Kurutma maliyet yerinde ortaya çıkan 1.528.615 TL'lik üretim maliyetinin 647.155 TL'lik kısmı (\%42'si) direkt işçilik maliyetinden, 881.460'lik kısmı (\%58'si) genel üretim maliyetinden oluşmaktadır.

Üretim maliyetinin en fazla ortaya çıkan maliyet yeri, pişirme maliyet yeridir. Pişirme maliyet yerinde ortaya çıkan 3.512.479 TL'lik üretim maliyetinin 2.057.365 TL'lik kısmı (\%59'u) direkt işçilik maliyetinden, 1.455.114 TL'lik kısm1 (\%41'si) genel üretim maliyetinden oluşmaktadır. Genel üretim maliyeti içerisinde de \%82'lik payla en fazla kömür maliyeti oluşmuştur.

Tuğla fabrikasının 2018 ve 2019 yılları için üretim maliyetlerindeki değişimi göstermek için Tablo 12 oluşturulmuştur.

Tablo 12. Yıllara Göre Maliyet Değişimi

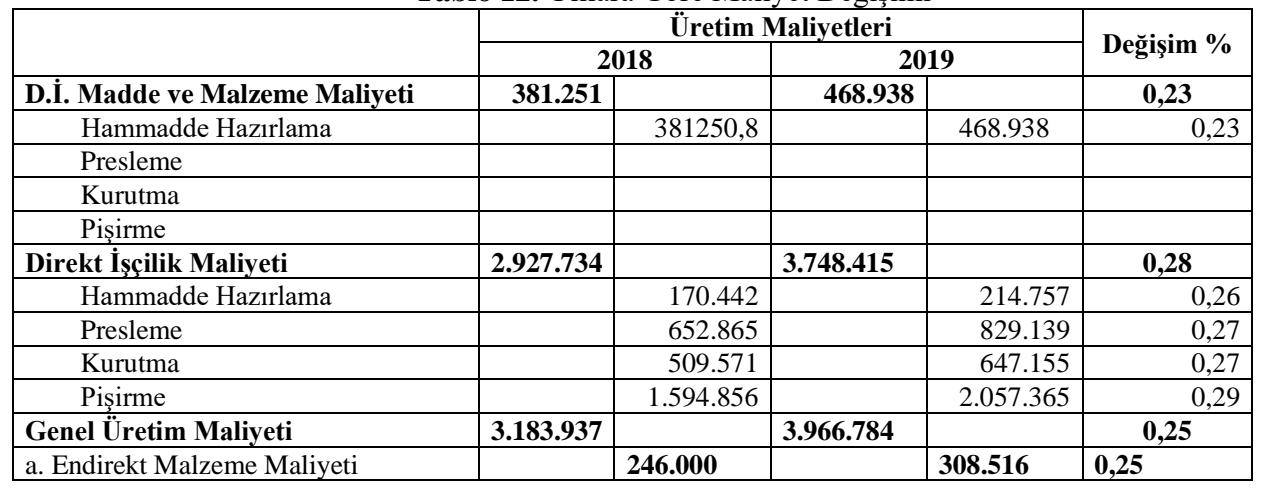




\begin{tabular}{|c|c|c|c|c|c|}
\hline Hammadde Hazırlama & & 108.559 & & 141.127 & 0,30 \\
\hline Presleme & & 44.184 & & 58.765 & 0,33 \\
\hline Kurutma & & 73.550 & & 84.583 & 0,15 \\
\hline Pişirme & & 19.706 & & 24.042 & 0,22 \\
\hline b. Endirekt İşçilik Maliyeti & & 391.680 & & 496.221 & $\mathbf{0 , 2 7}$ \\
\hline Hammadde Hazırlama & & 135.183 & & 173.035 & 0,28 \\
\hline Presleme & & 94.070 & & 118.528 & 0,26 \\
\hline Kurutma & & 95.765 & & 120.664 & 0,26 \\
\hline Pişirme & & 66.662 & & 83.994 & 0,26 \\
\hline c. Elektrik Maliyeti & & 644.745 & & 841.891 & $\mathbf{0 , 3 1}$ \\
\hline Hammadde Hazırlama & & 284.645 & & 370.039 & 0,30 \\
\hline Presleme & & 128.397 & & 166.916 & 0,30 \\
\hline Kurutma & & 186.099 & & 245.651 & 0,32 \\
\hline Pişirme & & 45.604 & & 59.285 & 0,30 \\
\hline d. Bakım Onarım Maliyeti & & 531.802 & & 665.562 & $\mathbf{0 , 2 5}$ \\
\hline Hammadde Hazırlama & & 234.682 & & 293.352 & 0,25 \\
\hline Presleme & & 95.520 & & 109.848 & 0,15 \\
\hline Kurutma & & 159.000 & & 214.650 & 0,35 \\
\hline Pişirme & & 42.600 & & 47.712 & 0,12 \\
\hline e. Yakıt Maliyeti & & 1.369.710 & & 1.654 .594 & $\mathbf{0 , 2 1}$ \\
\hline Hammadde Hazırlama & & 165.500 & & 198.600 & 0,20 \\
\hline \multicolumn{6}{|l|}{ Presleme } \\
\hline Kurutma & & 187.750 & & 215.913 & 0,15 \\
\hline Pişirme & & 1.016 .460 & & 1.240 .081 & 0,22 \\
\hline Üretim Maliyeti & 6.492 .922 & & 8.184.138 & & 0,26 \\
\hline
\end{tabular}

Tablo 12'de görüldüğü üzere fabrikanın üretim maliyetlerinin 2018 ve 2019 yıllarında oluşan direkt ilk madde ve malzeme, direkt işçilik ile genel üretim maliyeti karşılaştırmalı ve oluşan değişimlerde yüzde olarak verilmiştir. Direkt ilk madde ve malzeme maliyeti 2019 yılında 2018 yılan göre \%23 oranında artmıştır. $\mathrm{Bu}$ artıştan hem fiyat artışı hem de üretimde kullanılan hammadde miktar artış1 etkili olmuştur. Üretimde kullanılan hammadde miktarı Tablo 13 ve 14 'te görüldüğü üzere $56.932 .912 \mathrm{~kg}$ 'dan $60.570 .032 \mathrm{~kg}$ 'a çıkmıştır. Direkt işçilik maliyeti 2019 yılında, 2018 y1lan göre \% 28 oranında artmıştır. İşçilik maliyetindeki artış nedeni asgari ücrette yaşanan artıştan kaynaklanmıştır. Genel üretim maliyeti 2019 y1lında, 2018 yılan göre \%25 oranında artış olmuştur. Genel üretim maliyetinden endirekt malzeme maliyetinde $\% 25$, endirekt işçilik maliyetinde $\% 27$, elektrik maliyetinde $\% 31$, bakım onarım maliyetinde $\% 25$, yakıt maliyetinde $\% 21$ oranında artış olmuştur. Genel üretim maliyetlerindeki artışın nedeni hem üretim hem de fiyat artış kaynaklı olmuştur. Toplam üretim maliyeti 2019 yılında 2018 y1lan göre \%26 oranında artmıştır.

\section{Birim Maliyetler}

1.2018 Yılı Birim Maliyetler

2018 y1lı üretim miktarı Tablo 13'te gösterilmiştir.

Tablo 13. 2018 Y11 1 Üretim Miktarları

\begin{tabular}{|l|c|r|r|}
\hline \multicolumn{1}{|c|}{ Tuğla Çeşitleri } & $\begin{array}{c}\text { Üretim Miktarı } \\
\text { (Adet) }\end{array}$ & $\begin{array}{c}\text { Pişmiş Ağırlık } \\
\text { (Kg) }\end{array}$ & \multicolumn{1}{c|}{$\begin{array}{c}\text { Üretim Miktarı } \\
\text { (Kg) }\end{array}$} \\
\hline 8,5 'luk Tuğla & 2.550 .500 & 2,00 & 5.101 .000 \\
\hline 13,5'luk Tuğla & 17.856 .245 & 2,70 & 48.211 .862 \\
\hline Yığma Tuğla & 1.034 .300 & 3,50 & 3.620 .050 \\
\hline Toplam & $\mathbf{2 1 . 4 4 1 . 0 4 5}$ & & $\mathbf{5 6 . 9 3 2 . 9 1 2}$ \\
\hline
\end{tabular}


Tablo 13'te görüldüğü üzeri tuğla fabrikası 2018 yılında 3 çeşit tuğladan toplamda 21.441.045 adet tuğla üretmiştir. Üretilen tuğlalar $\mathrm{kg}$ olarak değerlendirildiğinde $56.932 .912 \mathrm{~kg}$ üretim yapılmıştır. Birim üretim maliyetini $\mathrm{kg}$ üretim miktarından hesaplama yapılmış ve kg üretim maliyeti;

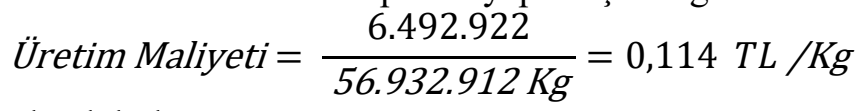

olarak bulunmuştur.

Mamullerin birim maliyetleri de şu şekilde tespit edilmiştir;

8,5 Tuğla: 2,00 kg/Adet $x 0,114 \mathrm{TL} / \mathrm{kg}=0,23 \mathrm{TL} /$ Adet

13,5 Tuğla: $2,70 \mathrm{~kg} /$ Adet $x 0,114 \mathrm{TL} / \mathrm{kg}=0,31 \mathrm{TL} /$ Adet

Yığma Tuğla: $3,50 \mathrm{~kg} /$ Adet $x 0,114 \mathrm{TL} / \mathrm{kg}=0,40 \mathrm{TL} /$ Adet

\section{2019 Yılı Birim Maliyetler}

2019 yılı üretim miktarı Tablo 14'te gösterilmiştir.

Tablo 14. 2019 Üretim Miktarları

\begin{tabular}{|l|r|r|r|}
\hline \multirow{2}{*}{ Tuğla Çeşitleri } & \multicolumn{1}{c|}{ Üretim Miktarı } & \multicolumn{1}{c|}{ Pişmiş Ağırık } & \multicolumn{1}{c|}{ Üretim Miktarı } \\
\cline { 2 - 4 } & \multicolumn{1}{c|}{ (Adet) } & \multicolumn{1}{c|}{$(\mathbf{K g})$} \\
\hline 8,5 'luk Tuğla & 2.678 .025 & 2 & 5.356 .050 \\
\hline 13,5'luk Tuğla & 19.106 .182 & 2,7 & 51.586 .692 \\
\hline Yığma Tuğla & 1.036 .369 & 3,5 & 3.627 .290 \\
\hline Toplam & $\mathbf{2 2 . 8 2 0 . 5 7 6}$ & & $\mathbf{6 0 . 5 7 0 . 0 3 2}$ \\
\hline
\end{tabular}

Tablo 14'te görüldüğü üzeri tuğla fabrikası 2019 y1lı için 3 çeşit tuğladan toplamda 22.820 .576 adet tuğla üretmiştir. Üretilen tuğlalar $\mathrm{kg}$ olarak değerlendirildiğinde $60.570 .032 \mathrm{~kg}$ üretim yapılmıştır.

Birim üretim maliyetini $\mathrm{kg}$ üretim miktarından hesaplama yapılmış ve $\mathrm{kg}$ üretim maliyeti;

olarak bulunmuştur.

$$
\ddot{\text { Uretim Maliyeti }}=\frac{8.184 .138}{60.570 .032 \mathrm{Kg}}=0,135 \mathrm{TL} / \mathrm{Kg}
$$

Mamullerin birim maliyetleri de şu şekilde tespit edilmiştir;

8,5 Tuğla: $2,00 \mathrm{~kg} /$ Adet $x 0,135 \mathrm{TL} / \mathrm{kg}=0,27 \mathrm{TL} /$ Adet

13,5 Tuğla: $2,70 \mathrm{~kg} /$ Adet $x 0,135 \mathrm{TL} / \mathrm{kg}=0,36 \mathrm{TL} /$ Adet

Yığma Tuğla: $3,50 \mathrm{~kg} /$ Adet x0,135 TL/kg =0,47 TL/Adet

Birim üretim maliyeti $\mathrm{kg}$ açısından 2018 y11 ile 2019 y11 karşılaştırıldığında \%18 (0,135 TL/kg / 0,114 TL/kg) oranında artış olduğu tespit edilmiştir. Toplam üretim maliyeti 2018 y1lında 6.492.922 TL iken 2019 y1lında 8.184.138 TL olmuştur. Toplam üretim miktarı kg olarak 2018 yılında 56.932 .912 $\mathrm{kg}$ iken 2019 yılında $60.570 .032 \mathrm{~kg}$ olmuştur. Toplam üretim miktarı adet olarak 2018 y1lında 21.441 .045 adet iken 2019 yilında 22.820 .576 adet olmuştur.

\section{SONUÇ VE ÖNERILER}

Yöneticilerin karar almalarında maliyet bilgilerinin önemi göz ardı edilemez. Üretim maliyet bilgilerinin doğru, zamanlı ve isteğe uygun olarak hazırlanması yöneticilerin alacağı kararların isabetli olmasında çok önemli bir paya sahiptir. Araştırmada Erbaa bölgesinde üretim yapan tuğla fabrikasının 2018 ve 2019 yılı üretim maliyetleri incelenmiş, üretim maliyetleri çeşit, maliyet yeri ve değişim oranı bakımından analiz edilmiştir. 
Maliyet çeşitleri bakımından 2018 yılı verilerine göre; direkt hammadde maliyetinin $\% 6$, direkt işçilik maliyetinin $\% 45$ ve genel üretim maliyetinin $\% 49$ 'luk paya sahip olduğu, 2019 y1lı verilerine göre; direkt hammadde maliyetinin \%6, direkt işçilik maliyetinin \%46 ve genel üretim maliyetinin \%48'lik paya sahip olduğu tespit edilmiştir. Elde sonuçlar Kaya'nın Eskişehir bölgesinde tuğla ve kiremit fabrikaları için yaptığı çalışmanın sonuçlarıyla (direkt ilk madde ve malzeme maliyeti $\% 6$ ve işçilik maliyeti $\% 45$ ) benzerlik göstermiştir. Türkiye'deki tuğla fabrikaları incelendiğinde emek yoğun şekilde üretim yaptığı gözükmektedir. Sektörün emek yoğun çalışması nedeniyle işçilik maliyetleri yüksek çıkmıştır. Üretim maliyetleri içerisinde en fazla paya sahip olan genel üretim maliyetinin 2018 yılı için endirekt malzeme $\% 9$, endirekt işçilik \%8, elektrik \%20, bakım onarım \%18 ve yakıt maliyeti \%43'lük paya sahip olduğu, 2019 yılı için \%8 endirekt malzeme, \%13 endirekt işçilik, \%21 elektrik, \%17 bakım onarım ve $\% 42$ 'de yakıt giderinden oluştuğu tespit edilmiştir. Genel üretim maliyeti içerisinde yakıt (mazot) ve kömür maliyetinin önemli paya sahip olduğunu da vurgulamak gerekir. Üretim maliyetleri içerisinde önemli paya sahip olan kömür maliyetini düşürmek için Erbaa'daki tuğla fabrikalarının miktar iskontosu elde etmek için ortak kömür alımı yaptığı da tespit edilmiștir.

Üretim maliyetlerini maliyet yerleri açısından değerlendirdiğimizde 2018 y1lı için üretim maliyetlerinin $\% 23$ 'ü hammadde hazırlama maliyet yerinde, $\% 15$ 'i presleme maliyet yerinde, \%19'i kurutma maliyet yerinde ve \%43'ü pişirme maliyet yerinde gerçekleştiği, 2019 y1lı için üretim maliyetlerinin \%23'ü hammadde hazırlama maliyet yerinde, $\% 16$ 's1 presleme maliyet yerinde, $\% 18$ 'i kurutma maliyet yerinde ve \%43'ü pişirme maliyet yerinde gerçekleştiği, oransal bazda önemli bir değişikliğin olmadığ 1 tespit edilmiştir. Üretimin en son aşaması olan pişirme aşaması üretim maliyetlerinin en fazla olduğu aşama olarak tespit edilmiştir. $\mathrm{Bu}$ aşamada üretilen tuğlaların bozuk çıkması üretim maliyetlerinin yükselmesine neden olmaktadır. Bu aşamada üretime daha fazla dikkat ederek üretim kayıplarının oluşması engellenmelidir. Tuğla fabrikaları safha üretim sistemine göre üretim yaptıkları için önceki aşamalardan gelen çiğ tuğlaların kusurlu olmaması gerekmektedir. Pişirme öncesi aşamalarda oluşan üretim kayıpları üretim sürecinin başına döndürülerek yeniden üretime dahil edilmektedir. Ancak pişirme aşamasında oluşacak üretim kayıplarının geri dönüşü olmamaktadır. Onun için pişirme öncesi aşamadan kusurlu yarı mamul sisteme girmemeli ve pişirme süreci iyi kontrol edilmelidir. Pişirme aşamasının maliyeti diğer aşamalardan hem yüksek olması hem de üretim kayıplarının geri dönüşünün olmaması bu aşamayı daha da önemli hale getirmektedir.

Üretim maliyetlerinin 2018, 2019 yıllar itibarıyla değişim oranı incelendiğinde direkt ilk madde ve malzeme maliyetinin \%23, direkt işçilik maliyetinin $\% 28$ ve genel üretim maliyetinin $\% 25$ oranında artış yaptı̆̆ 1 tespit edilmiştir. Toplam üretim maliyetindeki değişim \%26 oranında olduğu tespit edilmiştir.

Araştırmanın sonucunda 2018 maliyet verilerine göre birim üretim maliyeti kg olarak $0,114 \mathrm{TL}$, mamul olarak $8.5^{\prime}$ 'luk tuğla $0,23 \mathrm{TL}, 13.5^{\prime}$ 'luk tuğla $0,31 \mathrm{TL}$ ve 
y1 ̆̆ma tuğlada 0,40 TL olduğu, 2019 maliyet verilerine göre birim üretim maliyeti kg olarak 0,135 TL, mamul olarak 8.5'luk tuğla 0,27 TL, 13.5'luk tuğla 0,36 TL ve yığma tuğlada 0,47 TL olduğu tespit edilmiştir.

$\mathrm{Bu}$ çalışmanın sonucunda, işletmelerin bilanço ve gelir tablosundaki mali verileri kullanarak analiz edilmesinin yanında özellikle üretim işletmelerinin maliyetlerinin de tür ve maliyet yerlerine göre analiz edilebileceği ortaya konmuştur.

Üretim maliyetlerinin analiz edilmesiyle işletmelerin üretim maliyetlerini yıllar itibarıyla tespit ederek üretim maliyetlerinin yıllık değişimini çeşit ve maliyet yerlerine göre takip etme imkanı sağlanır. Maliyet değişiminin analizi, yönetim muhasebesi açısından hangi maliyet çeşidinde ve/veya maliyet yerinde ne kadarlık değişimin olduğunu tespit ederek olumsuzluk durumunda gerekli tedbirleri alabilme imkanı verecek ve yöneticilere maliyet kontrolü sağlamada yardımcı olacaktır.

$\mathrm{Bu}$ konuda araştırma yapacaklar için farklı bölgelerdeki tuğla ve kiremit fabrikalarının maliyetleri tür ve maliyet yerlerine göre analiz yapabilirler. Farklı bölgeler için yapılacak çalışmalar ile bölgesel maliyet farklılıklarının tespitine yardımcı olacaktır. Ayrıca, farklı sektörlerdeki işletmeler içinde maliyet analiz çalışması yapılabilir.

\section{Araştırma ve Yayın Etiği Beyanı}

Makalenin tüm süreçlerinde Yönetim ve Ekonomi Dergisi'nin araştırma ve yayın etiği ilkelerine uygun olarak hareket edilmiştir.

\section{Yazarların Makaleye Katkı Oranları}

Makalenin tamamı Dr.Öğr.Üyesi Ergin Temel tarafından kaleme alınmıştır.

\section{Çıkar Beyanı}

Yazarın herhangi bir kişi ya da kuruluş ile çıkar çatışması yoktur.

\section{KAYNAKÇA}

Bacıoğlu, A., Bacıŏlu, S. (2013) Tuğla ve Kiremit Üretim, Yatırım, İşletme. Yaman Ofset.

Blocher, E.J., Stout, D.E. and Cokins, Gary (2010). Cost Management, Library of Congress Cataloging-in-Publication Data, Fifth Edition

Büyükmirza, K., (2012). Döner Sermayeli Kuruluşlarda Maliyet Muhasebesi Sisteminin Oluşturulmasına Dönük Analiz Sonuçları, Sağlık Bakanlığı Döner Sermeyeli İşletmelerinde Maliyet Muhasebesi Sistemi Oluşturulması Projesi Rapor No. 3.

Can, A.V. (2006). Maliyet Muhasebesi. Adapazarı: Sakarya Kitapevi, 2.Bask1.

Demircan, V., Yilmaz, H. ve Binici, T. (2005). Isparta İlinde Elma Üretim Maliyeti Ve Gelirinin Belirlenmesi, Tarım Ekonomisi Dergisi, 11(2): 71 - 80

Doğan, Z., Hatunoğlu, Z., ve Diğerleri. (2012). Maliyet ve Yönetim Muhasebesi. İstanbul: Lisans Yayıncilik.

Erkol, Ü. Ve Ağırbaş, İ. (2011). Hastanelerde Maliyet Analizi ve Faaliyet Tabanlı Maliyetleme Yöntemine Dayalı Bir Uygulama, Ankara Üniversitesi Tıp Fakültesi Mecmuası, 64(2), 8795

Ertaş, F.C. (2016). Maliyet Muhasebesi. İstanbul: Beta Yayınları.

Esatoğlu AE, Ağırbaş İ, Payziner PD ve ark. Ankara Üniversitesi Tıp Fakültesi Hastaneleri'nde Maliyet Analizi. Ankara Üniversitesi Tıp Fakültesi Mecmuası 2010; 63:17-27

Kadirhanoğulları, İ.H., Karadaş, K., Külekçi, M., (2016). Iğdır İlinde Bal Üretim Maliyetinin Belirlenmesi Üzerine Bir Çalışma, Iğdır Üni. Fen Bilimleri Enst. Der. 6(4): 115-120, 
Karasioğlu, F ve Çam, V (2008). Sağlık İşletmelerinde Maliyet Analizi: Karaman Devlet Hastanesinde Birim Muayene Maliyetlerinin Hesaplanması, Niğde Üniversitesi İIBF Dergisi, Cilt:1, Sayı: 1, 15-24.

Kaya, M. Tuğla-Kiremit Sektörü Profili ve Eskişehir'in Sektördeki Yeri. Eskişehir.

Kısakürek, M.M. (2010) Hastane İşletmelerinde Maliyet Analizi: Cumhuriyet Üniversitesi Tıp Fakültesi Hastanesinde Bir Uygulama. Atatürk Üniversitesi İktisadi ve İdari Bilimler Dergisi, cilt 24 say1 3: 229-256.

Mut, S. Ve Ağırbaş, İ. (2014). Hastanelerde Maliyet Analizi: Ankara'da Hizmet Sunan İkinci Basamak Bir Kamu Hastanesi'nde Uygulama, Mehmet Akif Üniversitesi Sosyal Bilimler Enstitü Dergisi, Cilt 9 Sayı 18, 20217.

Pazarçeviren, S.Y. (2001). Maliyet Muhasebesi. Adapazarı: Sakarya kitapevi

Sevsay, H, Batum, U., Aktan, A ve Şahin, S. (2013). Turgutlu İnovasyon Temelli Kümelenme Stratejik Planı. Zafer Kalkınma Ajansı.

Şişman, C., B., Kocaman, İ., Gezer, E., (2006). Tekirdağ Yöresinde Üretilen ve Tarımsal Yapılarda Yaygın Olarak Kullanılan Tuğlanın Fiziksel ve Mekanik Özellikleri Üzerine BirAraştırma. Tekirdağ Ziraat Fakültesi Dergisi 3(1)

Soylular, B ve Ağırbaş, İ., (2016). Hastanelerde maliyet analizi ve ikinci basamak bir hastanede birim maliyet hesaplanmas1, Gülhane Tip Derg;58: 266-271

Syed, M.S., Safeer, A. ve Saleem, M. (2016). Manufacturing Of Sustainable Clay Bricks: Utilization Of Waste Sugarcane Bagasse and Rice Husk Ashes. Construction and Building Materials: $29-41$.

Şener, R. (2004). Maliyet Unsurları Muhasebesi. Ankara: Gazi Kitapevi.

Temel, E. (2017). Kümelenmenin Toprak Sanayinde Üretim Maliyetlerine Etkisi Üzerine Bir Araştırma TR 83 Bölgesi Erbaa Örneği. (Yayınlanmamış Doktora Tezi). Tokat. Gaziosmanpaşa Üniversitesi SBE

Temel, E. ve Ertaş, F.C., (2017). Kümelenmenin Toprak Sanayinde Üretim Maliyetlerine Etkisi Üzerine Bir Araştırma TR 83 Bölgesi Erbaa Örneği. Muhasebe ve Denetime Bakış, Sayı 54 sayfa $35-56$

The Brick Industriy (2006). Manufacturing of Brick. Virginia.1-7

Tuvanç, İ.A. ve Dağdemir, V. (2009). Erzurum İli Pasinler İlçesinde Silajlık Misır Üretim Maliyetinin Tespiti Üzerine Bir Araştırma, Atatürk Üniv. Ziraat Fak.Derg. 40 (1), 61-69

Yiğit, V. ve Ağırbaş, İ., (2004). Hastane İşletmelerinde Kapasite Kullanım Oranlarının Maliyetlere Etkisi: Sağlık Bakanlığı Tokat Doğum ve Çocuk Bakımevi Hastanesinde Bir Uygulama, Hacettepe Üniversitesi Sağlık İdaresi Dergisi. Cilt. 6, Sayı. 2, 141-162.

Yükçü, S. (2005). Yönetim Açısından Maliyet Muhasebesi. İzmir: Birleşik Matbaacılık.

\section{SUMMARY}

In the intense competitive environment, cost data obtained from cost accounting are very important for business managers to make decisions. As well as obtaining cost data, these data must be timely, appropriate, comparable, accurate and understandable. In order for managers to use cost data in decision making, they need to analyse costs according to type, cost location and annual changes. Cost analysis is an economical evaluation method that enables systematically collecting, classifying and analysing the costs of a product or service. Cost analysis helps managers in interpreting the relationships between the products or services produced by using the cost accounting information system and making decisions for the future of the businesses.

The aim of the research is to analyse the results obtained by determining the production costs in brick production in terms of variety, cost and annual change in order to control cost and performance. 
In the research, 2018-2019 production costs of the factory, which operates in Erbaa region and has a daily production capacity of 100,000 bricks, were examined and the production costs were analysed in terms of variety, cost and rate of change.

In the study, it was found that the brick factory incurred a production cost of $6.492 .922 \mathrm{TL}$ in $2018,381.251 \mathrm{TL}$ of this cost was the direct raw material and material cost, 2.927.734 TL was the direct labour cost and 3.301.537 TL was the general production. It was determined that it incurred a production cost of $8,184,138 \mathrm{TL}$ in $2019,468,938 \mathrm{TL}$ of this cost was the direct raw material and material cost, 3,748,415 TL was the direct labour cost and 3,966,784 TL was the general production cost.

As a result of the analysis of cost types as a percentage, it was seen that the direct raw material cost had a share of $6 \%$, the direct labour cost $45 \%$ and the general production cost $49 \%$ according to 2018 data. According to the data of 2019, it was determined that direct raw material cost $6 \%$, direct labour cost $46 \%$ and general production cost $48 \%$. In 2018, indirect materials had the largest share of $9 \%$, indirect labour $8 \%$, electricity $20 \%$, maintenance and repair $18 \%$, and fuel cost $43 \%$, and $8 \%$ indirect materials for $2019,13 \%$ indirect labour, $21 \%$ electricity, $17 \%$ maintenance and repair and $42 \%$ fuel costs. Labour-intensive work of the sector has been effective in the high labour share.

When we evaluate the production costs in terms of cost, $23 \%$ of the production costs for 2018 were at the raw material preparation, $15 \%$ at the pressing, $19 \%$ at the drying, and $43 \%$ at the baking. It has been determined that $23 \%$ is at the raw material preparation, $16 \%$ at the pressing, $18 \%$ at the drying and $43 \%$ at the baking.

When the rate of change of production costs by 2018 and 2019 is analysed, it is determined that direct raw material and material cost increased by $23 \%$, direct labour cost by $28 \%$, general production cost by $25 \%$ and total production cost by $26 \%$.

As a result of the research, the unit production cost for 2018 was $0.114 \mathrm{TL}$ in $\mathrm{kg}, 0.23 \mathrm{TL}$ for 8.5 brick, 0.31 TL for 13.5 brick and $0.40 \mathrm{TL}$ for masonry brick for 2019. The cost was determined as $0.135 \mathrm{TL}$ in $\mathrm{kg}, 0.27 \mathrm{TL}$ for $8.5 \mathrm{~cm}$ brick, $0.36 \mathrm{TL}$ for 13.5 brick and $0.47 \mathrm{TL}$ for masonry brick. 